\title{
Peningkatan Produktifitas dan Variasi Usaha Ekonomi Perempuan Pengrajin Batik Desa Wonorejo Kecamatan Singosari Kabupaten Malang melalui Pelatihan Intensif Batik Tulis Kantil
}

\author{
Djoko Dwi Kusumojanto1, Yana Respati Dewi², Adelia Shabrina Prameka3*, Andro Agil Nur \\ Rakhmad ${ }^{4}$ \\ 1,2,3,4,Universitas Negeri Malang, Jurusan Manajemen \\ *Email : adelia.shabrina.fe@um.ac.id3
}

DOI: doi.org/10.52593/svs.02.1.01

Naskah diterima: 25 November 2021, direvisi 07 Desember 2021, disetujui: 26 Januari 2021

\begin{tabular}{l}
\hline Abstract \\
\hline Keywords: \\
batik, training, \\
community service, \\
women, MSMEs
\end{tabular}

Abstrak Kata kunci: Batik, pelatihan, pengabdian masyarakat, perempuan, UMKM

\begin{abstract}
Community service can be realized by implementing the empowerment of the surrounding community as a form of higher education's responsibility to Indonesia's human development as a whole. So that development must be a social change that not only occurs at the level of life of the community but also in the role of the elements in it. The form of community service that will be carried out by the proposer team is through community empowerment with the target being Increasing Productivity and Economic Variation of Women Batik Artisans Wonorejo Village Singosari District of Malang through Intensive Training batik Tulis Kantil. The implementation of community service is carried out by providing vocational training in batik tulis, namely training in making batik tulis and crafting souvenirs from batik tulis made. Participants are brought in professional healers in order to learn and be built directly on how to correctly. In addition to making batik tulis, trainees are also given training in making souvenirs from batik cloth. The aim of this training is to form selfemployed entrepreneurs and be part of improving Indonesia's creative economy.
\end{abstract}

\section{PENDAHULUAN}

Hakikat pembangunan nasional adalah pembangunan manusia Indonesia seutuhnya dan pembangunan masyarakat Indonesia seluruhnya. Dalam pelaksanaannya perlu ada keselarasan, keserasian, keseimbangan, dan kebulatan yang utuh dalam seluruh kegiatan pembangunan dengan subyek dan obyek pembangunannya adalah manusia dan masyarakat 
Indonesia, sehingga pembangunan harus berkepribadian Indonesia, menghasilkan manusia dan masyarakat maju dengan tetap berkepribadian Indonesia. Pembangunan ini dilaksanakan bersama oleh masyarakat dan Pemerintah. Masyarakat adalah pelaku utama pembangunan dan pemerintah berkewajiban untuk mengarahkan, membimbing, serta menciptakan suasana yang menunjang. Kegiatan masyarakat dan kegiatan Pemerintah saling mendukung, saling mengisi, dan saling melengkapi dalam satu kesatuan langkah menuju tercapainya tujuan pembangunan nasional seperti termaktub dalam Pembukaan UUD 1945.

Perguruan tinggi merupakan salah satu lembaga yang wajib berperan serta dalam mewujudkan tujuan pembangunan nasional. Kewajiban dari dosen sebagai salah satu civitas akademika Perguruan Tinggi adalah melaksanakan Tri Dharma Perguruan Tinggi yang meliputi pendidikan, penelitian dan pengabdian kepada masyarakat. Pengabdian masyarakat dapat diwujudkan dengan melaksanakan pemberdayaan masyarakat sekitar sebagai bentuk dari tanggung jawab Perguruan Tinggi terhadap pembangunan manusia Indonesia seutuhnya. Sehingga pembangunan harus merupakan perubahan sosial yang tidak hanya terjadi pada taraf kehidupan masyarakat belaka tetapi juga pada peranan unsur-unsur didalamnya.

Pemberdayaan masyarakat dalam penanggulangan kemiskinan menjadi komitmen bersama antara pemerintah pusat dengan pemerintah daerah. Kemiskinan merupakan masalah pembangunan kesejahteraan sosial yang berkaitan dengan berbagai bidang pembangunan lainnya yang ditandai oleh pengangguran, keterbelakangan, dan ketidakberdayaan. Desa Wonorejo terletak di wilayah Kecamatan Singosari, Kabupaten Malang.

Desa Wonorejo memiliki potensi yang cukup tinggi untuk dikembangkan. Potensi dan peluang banyak ditemukan pada Desa Wonorejo, sebagai wujud dari pemberdayaan masyarakat, maka pengabdian masyarakat ini akan memberikan pelatihan tambahan bagi para pelaku usaha sebagai tambahan varian usaha mengingat bahwa antusias warga terhadap pembuatan batik sangat tinggi akan tetapi hingga saat ini program pemerintah setempat belum memberikan kesempatan bagi pelaku usaha batik untuk mengembangkan dan mengasah ketrampilan mereka.. Usaha yang mereka jalankan sebagai bekal untuk menapaki kemandirian hidup ini sangat dibutuhkan di lingkungan masyarakat dengan kondisi yang minim lapangan kerja seperti di Negara kita saat ini. Maka dibutuhkan suatu cara untuk menumbuhkan semangat kemandirian di lingkungan masyarakat yang masih produktif dengan konsep kewirausahaan.

Pelatihan kewirausahaan (Kusumajanto, 2019) didasarkan pada kearifan ocal budaya batik tulis agar seluruh masyarakat terlebih generasi muda bisa menghargai dan melestarikannya sebagai bagian kewajiban warga Negara untuk mencintai budaya sendiri. Batik tulis telah ditetapkan UNESCO sebagai budaya non ocal asli Indonesia pada tanggal 2 Oktober 2009. Kita semua mempunyai tugas mulia untuk memberikan edukasi dan penanaman nilai-nilai kearifan ocal kepada generasi muda. Batik tulis dalam proses pembuatannya mengandung nilai-nilai budaya, nilai-nilai vokasional dan kompetensi diri, nilai-nilai ekonomis yang bisa menjadikan sasaran Kajian Pengalaman Lapangan menjadi pribadi yang mandir (Winarno dkk, 2021). Berdasarkan latar belakang tersebut, maka pengusul akan melaksanakan pelatihan pembuatan kerajinan dari batik tulis dalam bentuk souvenir kepada pelaku usaha batik desa Wonorejo, pengetahuan dan sikap dalam memasuki dunia wirausaha yang mandiri. Disamping itu, peserta akan diberikan pemahaman yang meliputi pembinaan fisik, mental, kemandirian maupun pelatihan keterampilan agar memiliki motivasi, etos kerja yang tinggi dan dapat menghasilkan karya-karya yang unggul sehingga mampu bersaing di dunia luar.. 


\section{METODE}

Dari permasalahan ditemukan di lapangan sesuai kesepakatan bersama antara mitra pelatih, desa binaan dan tim pengabdian masyarakat, maka perlunya solusi untuk membantu memecahkan permasalahn tersebut. Metode pendekatan sosial digunakan dalam pengabdian ini guna memotivasi masyarakat agar mau bergerak dan membentuk komunitas atau grup tetap jangka Panjang (Suyanto, 2015). Metode pendekatan ini dasarnya dilakukan berbasis kelompok, seluruh tahapan dan kegiatan yang telah dilakukan kepada masyarakat dilakukan secara berkelompok. Berikut metode pendekatan yang akan diterapkan dalam program pengabdian masyarakat ini antara lain:

1) Berbasis Potensi Lokal

a. Kunjungan industri pada usaha industri batik tulis kantil Kota Malang

b. Survey ke Desa Wonorejo dan rekruitmen sepuluh (10) calon peserta pelatihan

c. Melakukan pengamatan dan identifikasi kebutuhan biaya dan sarana prasarana untuk menunjang pelatihan kewirausahaan

2) Komprehensif

a. Memberikan kesempatan pelatihan bagi peserta di Industri batik tulis yang ada di Desa Wonorejo

b. Pelatihan dan pembimbingan oleh ahlinya, yang rencananya akan mengundang pembatik asli dari perwakilan Batik Tulis Kantil yaitu Yoessy Modest

c. Memberikan bantuan sarana dan prasarana yang digunakan untuk membuat batik tulis dan produk souvenir dari batik tulis

d. Melakukan pengawasan dalam proses pelatihan dan pelaksanaan pembuatan produk berupa batik tulis dan kerajinan souvenir dari batik tulis.

e. Mengevaluasi dan mengidentifikasi hambatan-hambatan yang mungkin muncul dalam prosesnya, dan melakukan penyelesaian masalahnya.

Berikut langkah pelaksanaan pengabdian masyarakat pelatihan membatik tulis:.

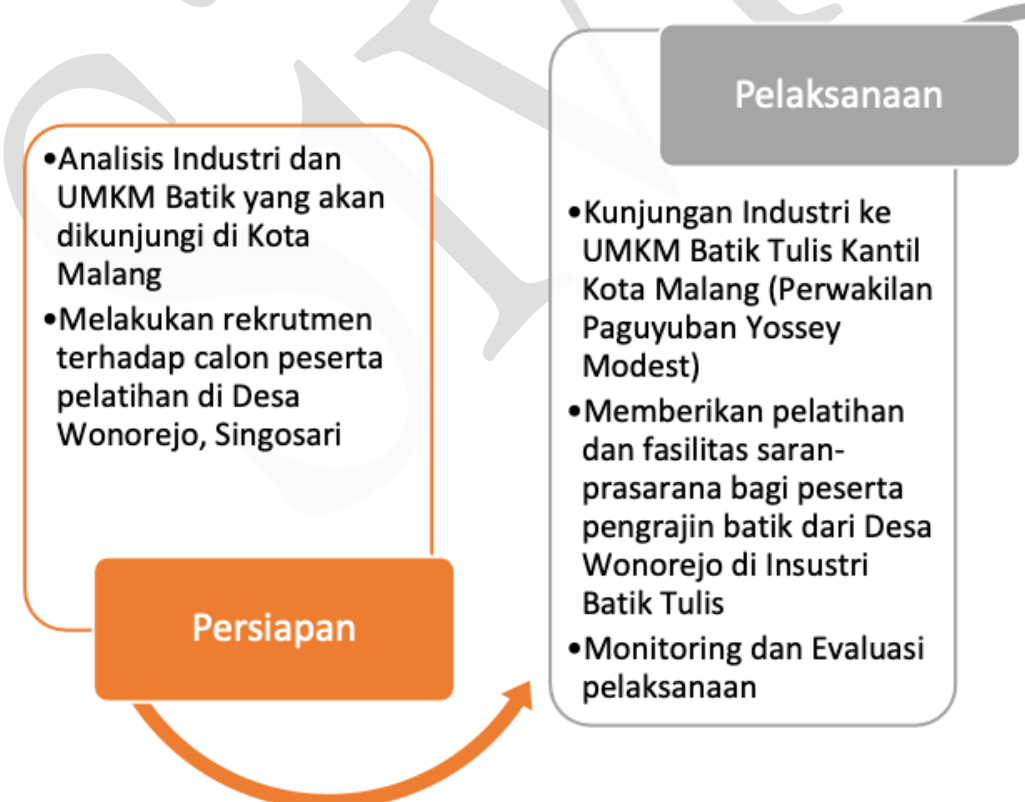

- Penyusunan laporan akhir -Penyusunan Artikel Jurnal -Penyusunan Artikel Media Masa

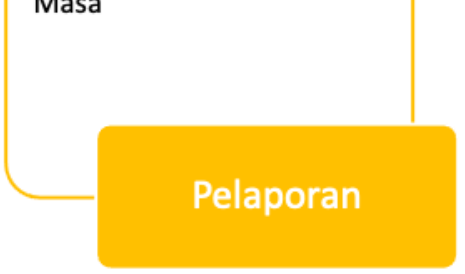

Gambar 1 - Metode Pelaksanaan Pengabdian Masyarakat Pelatihan Intesnif Membatik Desa Wonorejo

\section{Kolaborasi dengan lembaga sejenis di luar kampus dan pola operasinya}

Kolaborasi dengan lembaga sejenis di luar kampus akan dilakukan yaitu dengan BUMDES Wonorejo yang telah dijabarkan pada bab pendahuluan. Langkah operasionalnya adalah 
lembaga tersebut menyediakan peserta pelatihan yaitu dari anggota terutama para wanita untuk dibimbing, dididik, dibina dan dilatih menjadi wirausaha muda yang mengarah pada pembuatan industri kreatif yang mewadahi mereka yang tidak mendapatkan ilmu pengetahuan dari sekolah-sekolah formal dan lembaga kursus berbayar lainnya. Kolaborasi dilakukan untuk meningkatkan kepercayaan masyarakat terhadap usaha peningkatan wirausaha mandiri sebagai wujud dari program pengabdian masyarakat yang dilakukan.

\section{Jumlah tenant yang menjadi wirausaha}

Target jumlah tenant dalam pengabdian masyarakat ini adalah 10 orang peserta pelatihan perempuan usia produktif yang memiliki keinginan untuk berwirausaha mandiri dan belajar membatik langsung di mitra pelatihan Batik Tulis Kantil Yoessi

\section{HASIL DAN PEMBAHASAN}

Universitas Negeri Malang sebagai pusat pendidikan inovasi pembelajaran dan pusat incubator pembinaan desa dalam bidang pengabdian masyarakat. Sesuai dengan tujuan pengabdian yang hendak dicapai, maka tim pengabdian sangat mengupayakan keberhasilan kegiatan pengabdian masyarakat ini seratus persen. Indikator keberhasilan pencapaian tujuan ditunjukkan oleh beberapa kegiatan, yaitu:

1) Terjalinnya kerjsama Mitra Pelatih sebagai ahli yaitu Batik Kantil Yoessy

a. Kunjungan Industri Mitra Pelatih

Tim Pengabdian melakukan kunjungan industri untuk melakukan perizinan dan observasi awal, dan bertenu dengan Ibu Yoessy pemilik Yoessy Batik Kantil dan paten desain gambar batik kantil. Melalui kunjungan awal tersebut tim pengabdian telah melakukan negosisasi dan rencana pelaksanaan teknis Kerjasama mitra membatik.

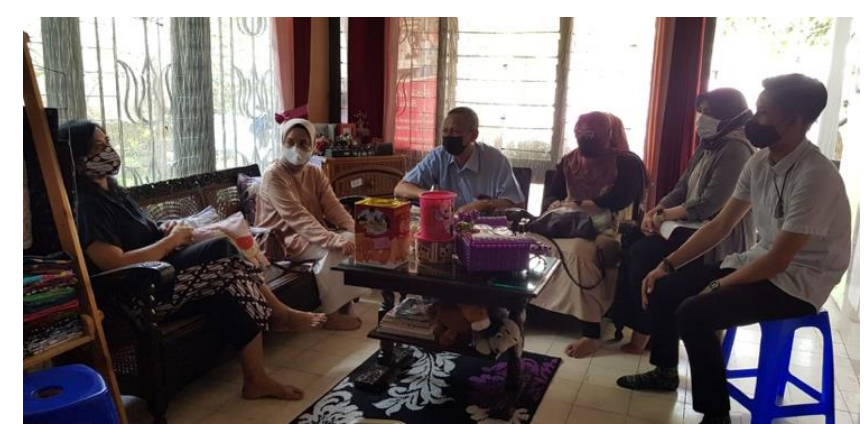

Gambar 2 - Kunjungan untuk Perizinan dan Observasi Awal dengan Ibu Yoessy.

b. Survey, observasi dan identifikasi kebutuhan biaya serta sarana prasarana untuk menunjang pelatihan kewirausahaan dan rekruitmen sepuluh (10) calon peserta pelatihan di Desa Wonorejo

Tm pengabdian melakukan survey langsung ke Desa Wonorejo Satu hari setelah mendapat rancangan teknis pelaksanaan Bersama Mitra Yoessy Modest. Kami langsung melakukan pengurusan ijin dengan perangkat desa diwakili oleh Bapak Sekertaris Desa dan melakukan rekrutmen peserta pelatihan. Rekrutmen calon peserta pelatihan dilakukan dengan berkoordinasi terpusat melalui pihak pembina Usaha Batik Desa Wonorejo (Ibu Siti Asyiah). Hari berikutnya kami meminta bantuan pembina dan perangkat desa untuk menyeleksi kesiapan dan kesediaan calon peserta. 
Dari pertemuan ini tim pengabdian telah mendapatkan 10 peserta terpilih dari para pelaku UKM Membatik Wonorejo termasuk dengan perwakilan perangkat Desa Wonorejo.

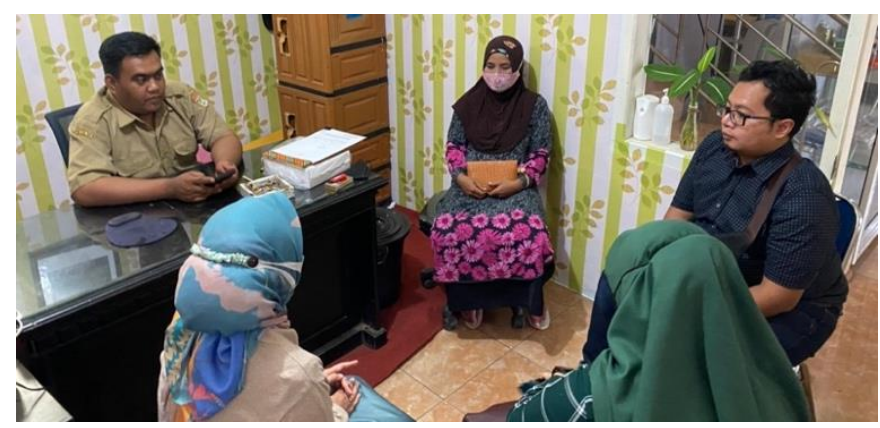

Gambar 3 - Kunjungan Survey di Kantor Desa Wonorejo Bersama Sekertaris Desa dan Pembina Utama Usaha Batik Desa Wonorejo (Ibu Siti Asyiah)

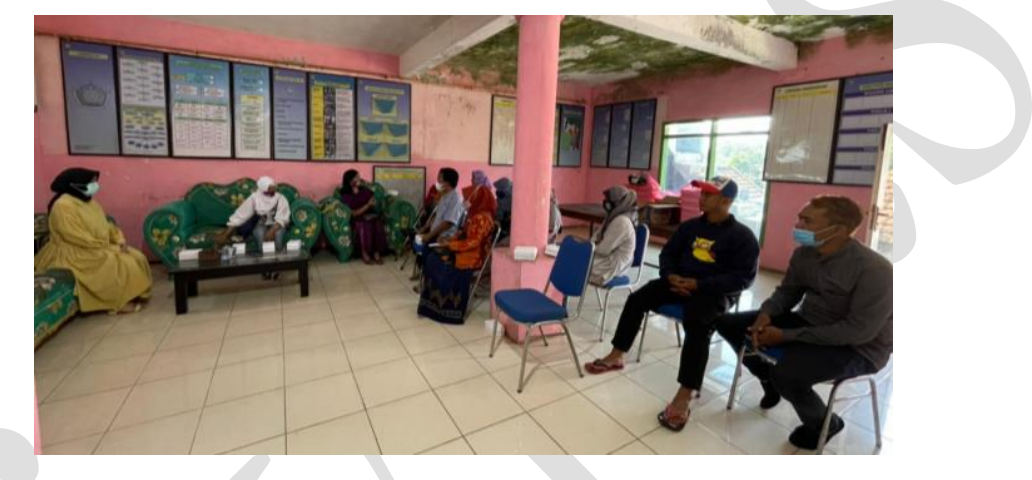

Gambar 4 - Rekruitmen calon peserta pelatihan

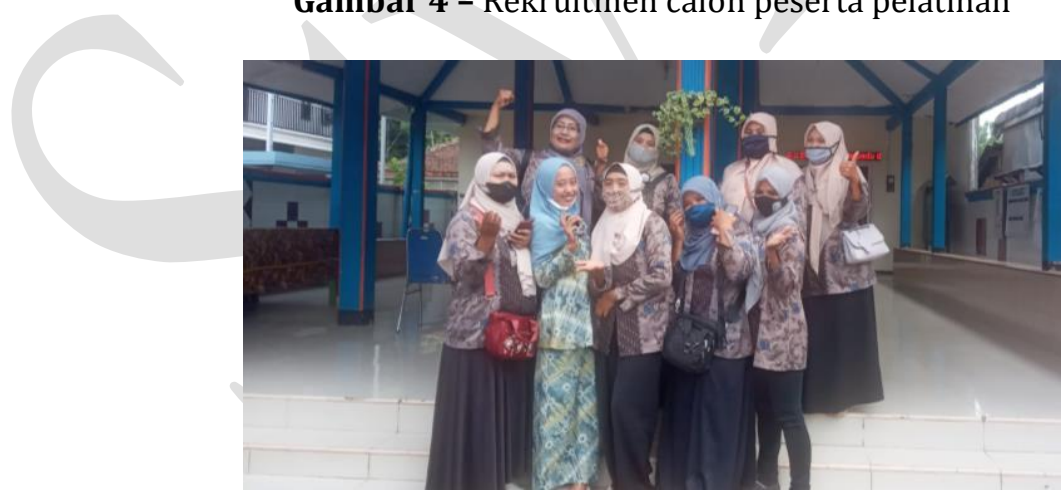

Gambar 5 - Peserta pelatihan batik tulis (perempuan pengrajin batik Desa Wonorejo)

2) Komprehensif Pelatihan

a. Adanya hasil Pelatihan, Pembimbingan dan Pengawasan Kelompok Perempuan Pengrajin Batik.

Pengabdian masyarakat ini memberikan peningkatan produktifitas dan variasi usaha ekonomi perempuan pengrajin batik Desa Wonorejo Kecamatan Singosari Kabupaten Malang melalui pelatihan intensif batik tulis kantil. Mitra desa binaan (perempuan pengrajin batik Desa Wonorejo) mampu mengikuti keseluruhan tahapan pengabddian dengan baik dan lancer. Mitra Pelatihan pun juga sangat telaten dan sabar dalam memberikan motivasi dan materi kepada para peserta dari mitra desa binaan. Antusiasme mengikuti kegiatan juga ditampakkan selama 
pelatihan berlangsung, mereka dapat menyalurkan ide kreatif dalam pewarnaan membatik, penentuan gambar corak batik, hingga membuat kreasi corak batik tulis kantil. Pembimbingan dan pengawasan juga dilakukan oleh tim Batik Kantil Yossie, yaitu Bu Yoessie sendiri dibantu oleh satu orang tim secara maksimal. Dengan menyelesaikan pekerjaan secara berkelompok dan pembagian pembimbingan dan pengawasan, membuat pelatihan dan pembimbingan lebih efisien, efektif dan intensif.

b. Adanya bantuan peralatan dan bahan membatik (canting, malam, kain mori, dan desain motif batik untuk dijiplak)

Sarana bantuan alat ini mendorong mitra desa binaan untuk bisa memanfaatkan pelatihan dan bantuan membatik secara maksimal.

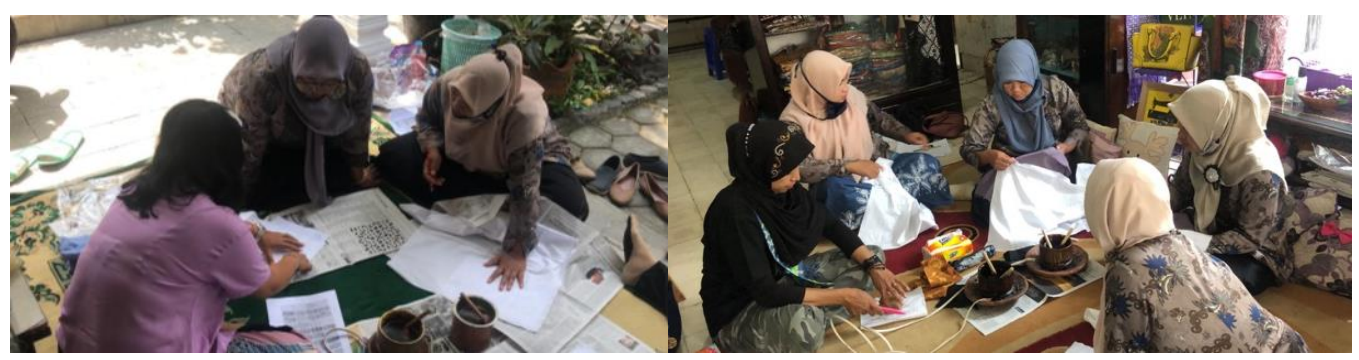

Gambar 6 -Pembimbingan dan Pengawasan Pelatihan secara Berkelompok

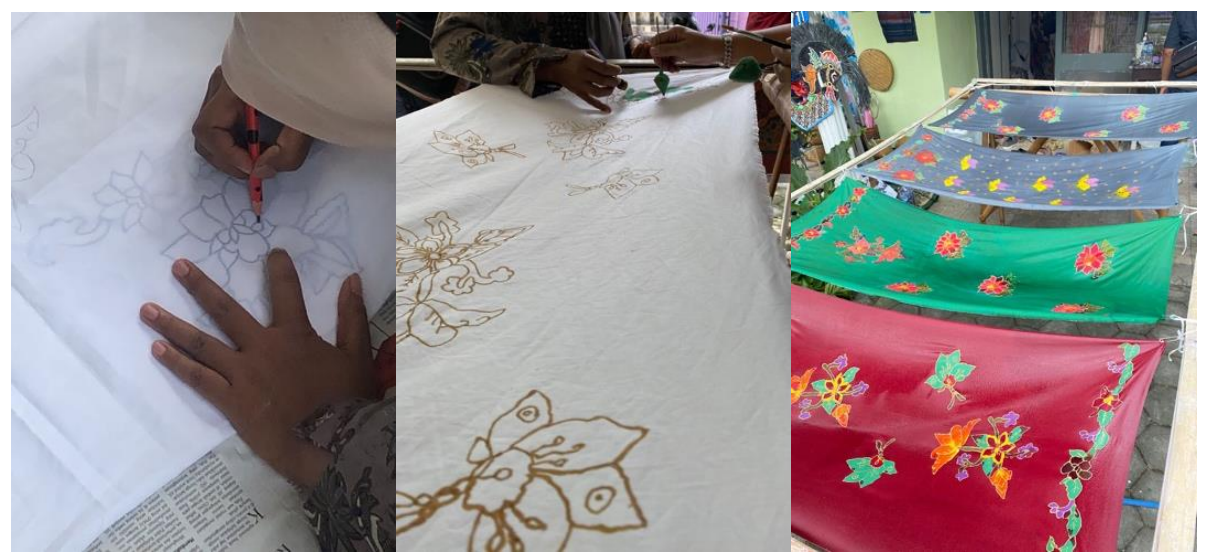

Gambar 7 -Proses Pelatihan Membatik hingga Pewarnaan Hasil Akhir

Eksistensi batik kantil sudah dikenal luas oleh masyarakat, hal ini menjadi kebanggan tersendiri bahwa tim pengabdian masyarakat UM mampu bekerjasama dan menjadikannya sebagai Mitra Pelatihan. Karya batik Kantil telah memiliki ciri khas dengan gambar bunga kantil dan cempaka. Ciri khas batik ini dapat diaplikasikan secara mudah dan bisa dikombinasikan dengan motif lain. Filosofi dari pemilihan motif batik kantil ini juga memiliki nilai. Filosofi jawa kantil yang bermakna lengket dan itu yang mempesona. Harapan besar dari pengabdian ini dapat memberikan manfaat jangka panjang bagi para peserta, baik dari segi peningkatan produktifitas kreasi membatik di Desa Wonorejo dan meningkatkan variasi usaha ekonomi Desa Wonorejo. Tindak lanjut kegiatan ini setelah variasi usaha batik Desa Wonorejo bertambah tim memiliki misi lain untuk dapat mengikutkan produk Desa Wonorejo pada berbagai pameran yang diselenggarakan oleh berbagai pihak, baik universitas ataupun dinas terkait. Keikutsertaan di dalam pameran tersebut adalah untuk memperkenalkan produk mitra desa binaan kepada masyarakat luas 


\section{KESIMPULAN Simpulan}

Kegiatan pengabdian kepada masyarakat yang telah terlaksana, dapat diambil kesimpulan bahwa peserta pengabdian telah mendapatkan keterampilan dan pengerahuan lebih tentang teknik membuat batik tulis, utamanya dengan motif batik kantil. Peserta pengabdian secara optimal dan antusias mengikuti proses pengabdian dari mulai observasi, seleksi hingga pelatihan dan menghasilkan hasil karya.

\section{Saran}

Keterampilan dan ilmu yang telah diperoleh oleh para peserta pengabdian diharapkan dapat ditularkan dan diteruskan menjadi sebuah kegiatan usaha berkelanjutan dan menjadi diversifikasi teknik dan variasi usaha batik di Desa Wonorejo. Lebih lanjutnya untuk mensukseskan batik Wonorejo menjadi batik khas desa dan terkenal hingga keluar Malang maka perlunya Kerjasama dan pemantauan dari triplehelix (universitas, pelaku bisnis dan pemerintah) untuk kegiatan berkelanjutan.

\section{UCAPAN TERIMA KASIH (Bila Perlu)}

Penulis mengucapkan terima kasih kepada Universitas Negeri Malang yang telah memberi dukungan financial terhadap pengabdian ini, dan tidak lupa terima kasih atas kerjasamanya untuk para mitra, baik mitra pelatihan dan mitra desa binaan.

\section{DAFTAR PUSTAKA}

Kementrian Pendidikan dan Kebudayaan Republik Indonesia. Undang-Undang Republik Indonesia Nomor 20 tahun 2003 tentang Sistem Pendidikan Nasional. 2003. Bandung : Citra Umbara.

Kusumanjanto, D. D., Mentari, D. A., Kartikasari, H., \& Basuki, A. (2019). Pemberdayaan Bagi Anak Asuh Lembaga Windyas Club Melalui Peningkatan Vokasional Batik Tulis Menuju Ekonomi Kreatif. Jurnal KARINOV, 2(1), 15-18.

Rahmawati.2000. Pendidikan Wirausaha dalam Globalisasi, Liberty, Yogyakarta

Ristekdikti.2017.Panduan Pelaksanaan Penelitian dan Pengabdian kepada Masyarakat di Perguruan Tinggi - Edisi XI.Jakarta :Ristekdikti

Suyanto, B. (2015). Metode Penelitian Sosial: Berbagai Alternatif Pendekatan: Prenada Media.

Winarno, A., Rohmaniyah, E. N., Rosyida, N. I., \& Juang, G. B. (2021). PENGEMBANGAN BATIK KONTEMPORER DENGAN TEKNIK COLET GRADASI UNTUK MENINGKATKAN VARIAN PRODUK BATIK SUJO DI DESA SUMBEREJO, GEDANGAN. Jurnal Graha Pengabdian, 3(1), 59-67 